$1-1-1994$

\title{
The Impact of Prior Firm Financial Performance on Subsequent Corporate Reputation
}

Sue Annis Hammond

Kodiak Consulting

John W. Slocum, Jr.

Southern Methodist University

Follow this and additional works at: https://scholar.smu.edu/business_workingpapers

Part of the Business Commons

This document is brought to you for free and open access by the Cox School of Business at SMU Scholar. It has been accepted for inclusion in Historical Working Papers by an authorized administrator of SMU Scholar. For more information, please visit http://digitalrepository.smu.edu. 
The first author wishes to thank the Graduate School of Business at Bowling Green State University, Dorie Thompson, Nancy Boudreau, and Barbara Carlin for their assistance with this study. Portions of the paper will be presented at Academy of Management meetings, Dallas, TX, August, 1994.

THE IMPACT OF PRIOR FIRM FINANCIAL PERFORMANCE ON SUBSEQUENT CORPORATE REPUTATION

Working Paper 94-0601*

by

Sue Annis Hammond John W. Slocum, Jr.

\author{
Sue Annis Hammond \\ President, Kodiak Consulting \\ 6522 LaManga Drive \\ Dallas, TX 75248 \\ (214) 380-6523 \\ John W. Slocum, Jr. \\ Edwin L. Cox School of Business \\ Southern Methodist University \\ Dallas, TX 75275 \\ (214) 768-3157
}

* This paper represents a draft of work in progress by the authors and is being sent to you for information and review. Responsibility for the contents rests solely with the authors and may not be reproduced or distributed without their written consent. Please address all correspondence to John W. Slocum, Jr. 


\section{Abstract}

This study links corporate reputation, as measured by Fortune magazine's Most Admired list, with firm financial performance. Seven measures of financial risk and return were collected for a sample of 149 firms from two time periods, 1981 and 1986. The mean score of four attributes from the 1993 Fortune Most Admired list for the sample was then analyzed with the financial data through regression analysis. Two financial variables, standard Deviation of the Market Return of the Firm and Return on Sales, explained between .12 and .14 of subsequent reputation. The implication for management is that they can affect a firm's subsequent reputation by lowering financial risk and controlling costs. 
Investment bankers, corporate managers, recruiters, among others, routinely rely on reputations of firms in making a variety of decisions. A firm's reputation sends signals to these stakeholders about its products and business strategies compared to other firms within similar industries. Favorable reputations have been linked to the generation of above average returns for a firm, job candidates' initial decisions about pursuing contact with a firm, and in some cases, the firm's social responsibility (Fombrun and Shanley, 1990; Fryxell and Wang, 1994; Gatewood, Gowan and Lautenschlager, 1993; and McGuire, Sundgren and Schneeweis, 1988). The purpose of this study was to examine the relationship between a firm's past financial performance and its subsequent reputation over an extended period of time.

The relationship between a firm's reputation and its financial performance is complex. There are various reasons for this complexity. The first reason is that it takes profit to have the funds to invest in socially responsible activities. Cyert and March (1963) proposed that if an organization has slack, e. g., excess profits, this creates opportunities for the organization to invest in more socially responsible behaviors that satisfy stakeholder expectations than if the firm has little or no slack. To the degree that firms with slack do engage in discretionary socially responsible programs, these programs may increase the firm's reputation over later periods of time. Those firms without slack are at an economic disadvantage and therefore have 
less resources available to direct toward socially responsible behaviors.

A second reason for this complexity is explained through stakeholder theory. Cornell and Shapiro (1987) and Chakravarthy (1986) suggest that all stakeholders must be equally satisfied. Every firm has a broad range of stakeholders. Satisfying one group can be at the expense of another group. Cornell and Shapiro divide stakeholders into two groups; those that have an explicit contract with the firm (e.g., stockholders, bondholders) and those that have implicit contracts with the firm (e.g., customers, employees). If the implicit contract stakeholders become dissatisfied, they may try to exchange their implicit contract into a more explicit one. For example, if employees doubt the firm's implied employment contract, they may choose to unionize and thus create an explicit agreement. Besides the direct increase in dollars, an explicit agreement generally limits the firm's flexibility in work policies and procedures.

The third reason is that corporate reputation often represents stakeholders' perception of the quality of the firm's management. Researchers have found that stakeholders view a firm's reputation for social responsibility as one indication of its top managers' ability to effectively manage the firm within the changing environment (Alexander and Bucholtz, 1978; Bowman and Haire, 1975; Miles, 1987; Sethi, 1975; Sonnenfeld, 1981; and Ullmann, 1985). A decline in a firm's reputation for social 
responsibility may signal to stockholders that top managers are not scanning and interpreting their environment accurately and that management changes may be necessary to achieve a better "fit."

Perceptions of a firm's low social responsibility may also decrease the firm's ability to obtain capital at consistently favorable rates. Investors may consider less socially responsible firms to be riskier investments because of the possibility of government intervention. In contrast, if a firm is viewed as socially responsible, it may have a relatively low financial risk as a result of its more favorable relationship with the financial community. Firms that can borrow at lower rates can more easily satisfy their stakeholders claims than firms without this ability (Cornell and Shapiro, 1987). Socially responsible firms also. may have lower perceived market risk because they appear more sensitive to external events and thus are able to anticipate and 'control' their changing environment.

Another reason for mixed results in this field is that many researchers have used concurrent measures of social responsibility and economic performance. McGuire, et al. (1988) studied the relationship between financial performance and social responsibility over a ten-year period. There was little association between concurrent measures of social responsibility and stock-based measures of performance, although three accounting-based measures (return on assets, total assets and 
operating income growth) were significantly correlated with firms' social responsibility. A firm's past financial performance effect on its subsequent reputation for social responsibility has met with mixed results. Return on assets, sales growth, and asset growth were positively correlated with later perceptions of social responsibility. Risk measures correlated negatively with corporate social responsibility suggesting that a "low-risk firm and a firm with high return on assets will later have an image of high social responsibility (McGuire et al., p. 865)." Risk and return on assets were able to predict between 19 and 13 percent of a firm's future social responsibility reputation. McGuire et al. (1988) suggest that future researchers consider financial performance as a variable influencing social responsibility reputation rather than social responsibility reputation influencing financial performance. Over time, firms with high financial performance and low risk may be better able to afford to act in socially responsible behaviors than firms with low performance.

High concurrent correlations between social responsibility and financial performance may be artifacts of a researcher's measurement system. Since a firm's current financial performance may be explained partially by examining the firm's previous performance, researchers need to use longitudinal designs that measure performance at several points in time. 
Furthermore, without a widely accepted measure of social responsibility, it is difficult for researchers to replicate the findings of others. The literature reflects three widely used measures of social responsibility. First, experts are asked to evaluate a firm's corporate policies according to some established criteria. The validity of this measurement resides in the expertise of those persons making the assessments. Second, researchers have used content analysis of corporate annual reports and other documents to assess a firm's social responsibilities. Unfortunately, many of these documents are often of more public relations than informational value since many annual reports are written by professional public relations staffs. A third method has been to use Fortune magazine's list of the most admired companies. This measure has been widely used in prior studies (McGuire, et al., 1988; Fombrun and Shanley, 1990; Gatewood, et al., 1993; Chakravarthy, 1986). The use of the Fortune index is not without limitations. Fryxell and Wang (1994) state that the Fortune data base provides an accurate measure of a firm's financial performance and should be used to complement other measures of a firm's performance as part of a multiple measurement strategy. Their factor analysis indicated that the Fortune reputation index loaded on two factors-financial ends and capabilities and strategic means--that are highly correlated. They indicate that the raters' judgments are heavily influenced by their financial evaluation of the firm and argue that the distinction between the factors, as independent constructs, is unlikely. To assess a firm's reputation for 
social responsibility over time, we used four of the five items that Fryxell and wang labeled capabilities and strategic means. These items measured the quality of management, its overall talent, and its relationships to key stakeholders.

\section{METHODS}

\section{Data}

Data on a firm's reputation were obtained from Fortune magazine's annual survey of corporate reputations. Fortune has conducted the survey for the past 11 years and published summary results in the January/February issue called "America's Most Admired Corporations." Over 8,000 executives and outside industry experts are asked to rate organizations within their industry on eight attributes: financial soundness, long-term investment value, use of corporate assets, quality of management, innovativeness, quality of products or services, wise use of corporate talent and community and environmental responsibility. The rating scale is from 0 (poor) to 10 (excellent).

The Fortune survey was chosen for several reasons. First, it provides comparable data over an extended period of time for a large number of firms in thirty-two diverse industries. Firms enter and leave the data set over time due to mergers or other changes in performance, but the sample is relatively stable. Second, the quality of respondents is comparable to those that 
could be obtained elsewhere since respondents only rate firms with which they are familiar. They have direct access to industry information that is salient to assess a firm's reputation. Third, McGuire, et al. (1988), Gatewood, et al. (1993), Fombrun and Shanley (1990), and Fryxell and Wang (1994) have used the instrument as a measure of a firm's reputation. This permits us to relate our findings to a broader body of literature.

To further refine the measure to reflect social responsibility, four of the eight attributes rated by Fortune's panel of industry experts were chosen as measures of social responsibility for this study. The four attributes are: quality of management; quality of products and services; ability to attract, develop and retain talented people; and community and environmental responsibility. The logic for selecting these four attributes is that three of the other measures used by Fortune are surrogate measures of a firm's financial performance. The fourth Fortune attribute, a measure of innovation, measures how well management responds to all its customers' demands for innovative products and/or services. Fortune (1993) indicated that while financial performance indicators had the most impact on a firm's reputation, how a firm's management responded to its key stakeholders was a better measure of its reputation than financial indicators. A corporation becomes "most admired" by increasing shareholder wealth and through positive relations with key stakeholder groups. Key stakeholders include: customers, represented by the quality of products and services rating; 
employees, represented by the measure of the ability to attract, develop and retain talented people; and the environment, represented by the community and environmental responsibility rating. Managing stakeholder relations and being aware and proactive to changes in the business environment is represented by the quality of management rating on the Fortune index (Miles, 1987; Sonnenfeld, 1981; Fombrun and Shanley, 1990; Chakravarthy, 1986; and Parket and Eilbert, 1975).

A varimax factor analysis was performed on these four items to empirically confirm that four items used to measure a firm's reputation loaded on a single factor. A single factor was extracted (Eigenvalue of 3.48 ) that explained 87 percent of the variance. To evaluate the internal consistency reliability of the four rating scales, we calculated a coefficient alpha. A coefficient alpha of .95 was obtained indicating a high internally consistent measure. These four items were averaged to arrive at a score representing a firm's reputation for social responsibility. Although some modification in a firm's ratings might be expected over time, we examined the ratings of a sample of 200 firms in the 1992 and 1993 Fortune list. The relationship between these ratings was .92 , indicating a firm's relative stability in its ranking over time. 
Ullmann (1985) has argued that conflicting results may derive, in part, from different measures of financial performance. For example, studies examining the relationship between social responsibility and accounting-based measures of performance have generally reported positive results (Parket and Eibert, 1975; Bowman and Haire, 1975). Cochran and wood (1984) also found a positive relationship after controlling for the age of a firm's assets. Spicer (1978b) and Aupperle, Carroll, and Hatfield (1985) found no relationship between market-based measures of performance and social responsibility.

To address prior conflicting results due to the use of either market or accounting measure of performance, we used a combination of market based measures of risk and return and accounting measures of return. The market measures of risk are: standard deviation of the market's average return (STDV), standard deviation of the market return of the company (STDC), the correlation coefficient between the market rate of return and the average firm's market return(R) and Beta. Beta (BETA) is calculated by dividing the sum of the covariance of the market (STDV times R) and the covariance of the firm (STDC times R) by the squared variance of the market (STDV squared).

The accounting measures included return on sales (net income divided by sales), asset turnover (sales divided by assets), leverage multiplier (assets divided by equity), and retention rate (1-dividends divided by net income). The rationale for 
choosing the accounting variables was to represent measures of a firm's efficiency (ROS), production (AT), quality financing (LM), and opportunities for the use of capital (B). Retention (B) represents the firm's ability to invest capital in opportunities that will provide a better rate of return to shareholders than dividends. These measures provide data to the investor on whether the rate of return is sufficient to justify the risk. The accounting variables can also be combined to create the more popular measures of return; Return on Equity and Sustainable Growth.

\section{Periods of Analysis}

This study collected from COMPUSTAT seven measures of risk and rate of return from companies on the 1993 Fortune list for two time periods: 1981 and 1986. The survey data reported in the 1993 Fortune list was collected in 1992 and reflects a firm's 1991 financial performance. Thus, a five and ten year time lag was employed. Various studies have used a five year (Alexander and Buchholz, 1978; Aupperle, Carroll and Hatfield, 1985; Bowman and Haire, 1975) and ten year (Abbott and Monson, 1979; Sturdivant and Ginter, 1977; Cochran and Wood, 1985 and McGuire, et al., 1988) period of time to study the relationship between a firm's financial performance and its reputation. Since return on sales and asset turnover do not have the same meaning in regulated industries, only non-regulated firms were included in 
the final sample. A total of 149 non-regulated firms were on the final list.

\section{RESULTS}

The study hypothesized that prior financial performance would be a salient predictor of a firm's future reputation as a socially responsible institution. Furthermore, we hypothesized that firms with higher financial returns will have achieved a higher score on Fortune's Most Admired List than firms with lower financial returns.

Table 1 shows the correlation between a firm's financial

Insert Table 1 about here

performance in 1981, 1986 and their reputation in 1993. The level of correlation between prior firm performance and later corporate social responsibility is weakly supported. The Standard Deviation of the Market (STDC) is negatively correlated with subsequent social responsibility for both years. This indicates that managers of firms that do not deliver the financial results expected by their shareholders were later perceived as being less socially responsible than managers of firms who delivered financial results expected by their stakeholders. Return on sales (ROS) was positively associated with later reputation. ROS measures the control of costs associated with obtaining sales. If 
a firm was able to control these costs, it was rated as being more socially responsible than firms that were not able to control these costs. There are mixed results for the other financial measures and later reputation.

The data in 1981 suggest that low-risk firms (as measured by Beta) and firms with high return on equity will have an image of high social responsibility. Unfortunately, the 1986 data indicate no support for this conclusion. High ROE in 1981 was positively associated with a good reputation in 1993. Once again, the 1986 data did not replicate these findings.

To test the multivariate relationship between corporate social responsibility and prior financial performance, we conducted two regressions. Since the financial performance data are somewhat correlated with each other (average correlation is $r=.16$; $p$ $<.05)$, care must be taken when interpreting these regressions. The results of the stepwise regressions for 1981 and 1986 using Fortune's ratings of social responsibility in 1993 as the independent variable indicated that only two financial measures-STDC and ROS--entered into the equation. The data in Table 2 indicates that 13 percent of a firm's reputational rating in

Insert Table 2 about here

1993 could be explained by a combination of STDC and ROS in 1981. STDC explained almost 10 percent of the variance, while ROS 
contributed 4 percent. The results from using a firm's 1986 financial performance were similar to 1981 financial indicators. STDC explained almost 9 percent of a firm's reputational rating in 1993, and ROS contributed 3 percent.

\section{DI8CO8sION}

The narrowest implication for management from our results is to control costs and deliver a return to investors as close to their expectations as possible. By achieving these goals, managers can control an average of $12 \%$ of their subsequent reputational score. This however, is a highly simplistic explanation. It is functional to look further into the question of stakeholder expectations to understand this relationship. Cornell and Shapiro (1987) theorize that stakeholders hold certain levels of expectations and will remain satisfied when their expectations are met. But what happens when their expectations are not met? If they don't get as much as they expected, they may choose to force a more explicit contract. Stockholders and institutional investors may become active and demand representation on the board. Customers may ask the government to intervene if they believe their expectations are ignored. All of these actions will cost the organization some autonomy in the way they conduct their business.

The results of this study suggest that in order to have the autonomy to operate the business franchise, management must be 
aware of and deliver the financial results expected by their stakeholders. This implies a much broader connection to stakeholders than previously conceptualized by past researchers. The traditional view of business as separate from society has evolved to how business legitimizes itself with society. The traditional way a business contributes to society and meets stakeholder expectation is through financial performance. Yet this suggests a precarious position for management; profit must be earned to 'pay' off the expectation of stakeholders, yet shortcuts that may lead to greater short-term profit may also create dissatisfaction with other stakeholders. This dissatisfaction could then result in a lower reputational score in subsequent years and a decline in profitability.

Miles (1987), Ullmann (1985) and Cyert and March (1963) all theorize that the ability to manage their environment is a complex managerial process. Considerations included are the amount of power the stakeholders possess, the philosophy of top management on how to relate to the environment, and the amount of slack earned by past economic and behavioral performance. These researchers also make the point that a firm is most admired when it can transform itself to take advantage of changes in an unknown and changing environment. Firms must have slack in order to be ready to take action when it is needed. The most admired firms in our sample were able to generate more slack (Return on Sales) than less admired firms over time and therefore, enjoyed a higher subsequent reputation. 
This study contributes to the understanding and theory that the construct of social responsibility ultimately seems to reflect the quality of management. The quality of management is the ability to anticipate problems and opportunities to meet expectations of all stakeholders and to be proactive in dealings with multiple stakeholders and the environment. The results from the study suggest that management will lower market risk by performing in a consistent manner. Since most investors are risk averse and the classic tradeoff is risk vs. return, short-term profit should not be the sole goal of management. The implication for management is that accommodating the needs of multiple stakeholders is a legitimate objective of the firm. 
Table 1

$$
\text { Correlation Between Corporate }
$$

social Responsibility and Firm Performance

Performance Indicators, 1981

Social Responsibility, 1993

$\begin{array}{lc}\text { STDC } & -.31 * * \\ \text { Beta } & -.17 * \\ \text { ROS } & .31^{* *} \\ \text { AT } & -.07 \\ \text { LM } & -.07 \\ \text { ROE } & .17 * \\ \text { Performance Indicators, } 1986 & \\ \text { STDC } & -.29 * * \\ \text { Beta } & .13 \\ \text { ROS } & .29 * * \\ \text { AT } & -.06 \\ \text { LM } & -.09 \\ \text { ROE } & -.03\end{array}$

$\star \quad \underline{p}<.05$

** $\underline{p}<.01$

(a) This is the average of the four items. 
Table 2

Results of Regression Analysis

Predicting 1993 Corporate social Responsibility

Financial Performance, 1981

$\begin{array}{cccc}\text { Beta } & \text { Adjusted } \\ \mathbf{R}^{2} & \mathbf{F}\end{array}$

$\begin{array}{lccc}\text { STDC } & -0.378 & -2.71 * * & \\ \text { ROS } & 5.26 & 2.65^{*} & 11.89 * *\end{array}$

.13

Financial Performance, 1986

$\begin{array}{llll}\text { STDC } & -0.35 & 2.52 * * & \\ \text { ROS } & 2.59 & 2.52 * * & .11\end{array}$

** $\mathrm{p}<.01$ 


\section{BIBLIOGRAPHY}

Abbott, W.F. and R. J. Monsen: 1979, 'On the measurement of corporate social responsibility: Self-reported disclosures as a method of measuring corporate social involvement', Academy of Management Journal 22 (3), 501-515.

Alexander, G.J. and R. A. Buchholz: 1978, 'Corporate social responsibility and stock market performance', Academy of Management Journal 21 (3), 479-486.

Arlow, P. and M. J. Gannon: 1982, 'Social responsiveness, corporate structure, and economic performance', Academy of Management Review 7 (2), 235-241.

Aupperle, K.E., A. B. Carroll, and J. D. Hatfield: 1985, 'An empirical examination of the relationship between corporate social responsibility and profitability', Academy of Management Journal 28 (2), 446-463.

Bowman, E.H. and M. Haire: 1975, 'A strategic Posture toward Corporate Social responsibility', California Management Review 17 (2), 49-58.

Carroll, A.B.: 1979, 'A three-dimensional conceptual model of corporate performance', Academy of Management Review 4 (4), 497-505.

Chakravarthy, B.: 1986, 'Measuring strategic performance', Strategic Management Journal 7, 437-458. 
Cochran, P.L. and R. A. Wood: 1984, 'Corporate social responsibility and financial performance', Academy of Management Journal 27 (1), 42-56.

Cornell, B. and A. Shapiro: 1987, 'Corporate stakeholders and corporate finance', Financial Management 16, 5-14.

Cyert, R.M. and J. G. March: 1963, A Behavioral Theory of the Firm (Prentice-Hall, Englewood Cliffs, NJ).

Fombrun, C. and M. Shanley: 1990, 'What's in a name? Reputation building and corporate strategy', Academy of Management Journal 33 (1), 233-258.

Fortune February 1992, 40-72. 'America's Most Admired Corporations'.

Fortune February 1993, 44-80. 'America's Most Admired Corporations'.

Fryxell, G.E. and J.Wang: 1994, 'The Fortune corporation 'Reputation' index: Reputation for what?,' Journal of Management 20 (1), 1-14.

Gatewood, R.D., M. A. Gowan, and G. J. Lautenschlager: 1993, 'Corporate image, recruitment image, and initial job choice decisions', Academy of Management Journal 36 (2), 414-427. McGuire, J.B., A. Sundgren, and T. Schneeweis: 1988, 'Corporate social responsibility and firm financial performance', Academy of Management Journal 31 (4), 854-872.

Miles. R.H.: 1987, Managing the Corporate Social Environment: A grounded theory (Prentice-Hall, Inc., Englewood Cliffs, NJ). Parket, R. and H. Eibert: 1975, 'Social responsibility: The underlying factors', Business Horizons, 18, 5-10. 
Sethi, S.P.: 1975, 'Dimensions of corporate social performance: An analytical framework', California Management Review, 17 (3), 58-64.

Sonnenfeld, J. A.: 1981, Corporate views of the public interest (Auburn House Publishing Company, Boston, MA) .

Spicer, B.H.: 1978a, 'Accounting for corporate social performance: Some problems and issues', Journal of Contemporary Business, 7, 151-170.

Spicer, B.H.: 1978b, 'Investors, corporate social performance and information disclosure: An empirical study', The Accounting Review, 53 (1), 94-111.

Sturdivant, F.D. and J. I. Ginter: 1977, 'Corporate social responsiveness: Management attitudes and economic perfomance', California Management Review, 19 (3), 30-39.

Ullmann, A.A.: 1985, 'Data in search of a theory: A critical examination among social performance, social disclosure, and economic performance of U.S. firms', Academy of Management Review, 10 (3), 540-557. 
Note: The following is a partial list of papers that are currently available in the Edwin L. Cox School of Business Working Paper Series. When requesting a paper, please include the Working Paper number as well as the title and author(s), and enclose payment of $\$ 2.50$ per copy made payable to SMU. A complete list is available upon request from:

Business Information Center Edwin L. Cox School of Business Southern Methodist University Dallas, Texas 75275 
90-0101 "Organizational Subcultures in a Soft Bureaucracy: Resistance Behind the Myth and Facade of an Official Culture," by John M. Jermier, John W. Slocum, Jr., Louis W. Fry, and Jeannie Gaines

90-0201 "Global Strategy and Reward Systems: The Key Roles of Management Development and Corporate Culture," by David Lei, John W. Slocum, Jr., and Robert W. Slater

90-0701 "Multiple Niche Competition - The Strategic Use of CIM Technology," by David Lei and Joel D. Goldhar

90-1001 "Global Strategic Alliances," by David Lei and John W. Slocum, Jr.

90-1002 "A Theoretical Model of Household Coupon Usage Behavior And Empirical Test," by Ambuj Jain and Arun K. Jain

90-1003 "Household's Coupon Usage Behavior: Influence of In-Store Search," by Arun K. Jain and Ambuj Jain

90-1201 "Organization Designs for Global Strategic Alliances," by John W. Slocum, Jr. and David Lei

91-0101 "Option-like Properties of Organizational Claims: Tracing the Process of Multinational Exploration," by Dileep Hurry

91-0701 "A Review of the Use and Effects of Comparative Advertising," by Thomas E. Barry

91-0901 "Global Expansion and the Acquisition Option: The Process of Japanese Takeover Strategy in the United States," by Dileep Hurry

91-0902 "Designing Global Strategic Alliances: Integration of Cultural and Economic Factors," by John W. Slocum, Jr. and David Lei

91-1001 "The Components of the Change in Reserve Value: New Evidence on SFAS No. 69," by Mimi L. Alciatore

91-1002 "Asset Returns, Volatility and the Output Side," by G. Sharathchandra

91-1201 "Pursuing Product Modifications and New Products: The Role of Organizational Control Mechanisms in Implementing Innovational Strategies in the Pharmaceutical Industry," by Laura B. Cardinal 
92-0101 "Management Practices in Learning Organizations," by Michael McGill, John W. Slocum, Jr., and David Lei

92-0301 "The Determinants of LBO Activity: Free Cash Flow Vs. Financial Distress Costs," by Tim Opler

92-0302 "A Model of Supplier Responses to Just-In-Time Delivery Requirements, " by John R. Grout and David P. Christy

92-0303 "An Inventory Model of Incentives for On-Time Delivery in Just-In-Time Purchasing Contracts, " by John R. Grout and David P. Christy

92-0304 "The Effect of Early Resolution of Uncertainty on Asset Prices: A Dichotomy into Market and NonMarket Information," by G. Sharathchandra and Rex Thompson

92-0305 "Conditional Tests of a Signalling Hypothesis: The Case of Fixed Versus Adjustable Rate Debt, " by Jose Guedes and Rex Thompson

92-0306 "Tax-Loss-Selling and Closed-End Stock Funds," by John W. Peavy III

92-0401 "Hostile Takeovers and Intangible Resources: An Empirical Investigation," by Tim C. Opler

92-0402 "Morality and Models," by Richard O. Mason

92-0501 "Global Outsourcing of Information Processing Services," by Uday M. Apte and Richard O. Mason

92-0502 "Improving Claims Operations: A Model-Based Approach," by Uday M. Apte, Richard A. Cavaliere, and G. G. Hegde

92-0503 "Corporate Restructuring and The Consolidation of U.S. Industry," by Julia Liebeskind, Timothy C. Opler, and Donald E. Hatfield

92-0601 "Catalog Forecasting System: A Graphics-Based Decision Support System," by David V. Evans and Uday M. Apte

92-0701 "Interest Rate Swaps: A Bargaining Game Solution," by Uday Apte and Prafulla G. Nabar

92-0702 "The Causes of Corporate Refocusing," by Julia Liebeskind and Tim C. Opler 
92-0801 "Job Performance and Attitudes of Disengagement Stage Salespeople Who Are About to Retire," by William L. Cron, Ellen F. Jackofsky, and John W. Slocum, Jr.

92-0901 "Global Strategy, Alliances and Initiative," by David Lei and John W. Slocum, Jr.

92-0902 "What's Wrong with the Treadway Commission Report? Experimental Analyses of the Effects of Personal Values and Codes of Conduct on Fraudulent Financial Reporting," by Arthur P. Brief, Janet M. Dukerich, Paul R. Brown and Joan F. Brett

92-0903 "Testing Whether Predatory Commitments are Credible," by John R. Lott, Jr. and Tim C. Opler

92-0904 "Dow Corning and the Silicone Implant Controversy," by Zarina S. F. Lam and Dileep Hurry

92-0905 "The Strategic Value of Leverage: An Exploratory Study," by Jose C. Guedes and Tim C. Opler

92-1101 "Decision Model for Planning of Regional Industrial Programs," by Uday M. Apte

92-1102 "Understanding the Linkage between Strategic Planning and Firm Performance: A Synthesis of more than Two Decades of Research," by $C$. Chet Miller and Laura B. Cardinal

92-1201 "Global Disaggregation of Information-Intensive Services," by Uday M. Apte and Richard O. Mason

93-0101 "Cost and Cycle Time Reduction in Service Industry: A Field Study of Insurance Claims Operation," by Uday M. Apte and G. G. Hegde

93-0301 "A Robust, Exact Alborithm for the Maximal set Covering Problem," by Brian T. Downs and Jeffrey D. Camm

93-0501 "The Economic Dependency of Work: Testing the Moderating Effects of Financial Requirements on the Relationship between Organizational Commitment and Work Attitudes and Behavior," by Joan F. Brett, William L. Cron, and John W. Slocum, Jr.

93-0502 "Unlearning the Organization," by Michael McGill and John W. Slocum, Jr. 
93-0503 "The Determinants of Corporate Bank Borrowing," by Linda Hooks and Tim C. Opler

93-0504 "Corporate Diversification and Innovative Efficiency: An Empirical Study," by Laura B.

Cardinal and Tim C. Opler

93-0505 "The Indirect Costs of Financial Distress," by Tim C. Opler and Sheridan Titman

93-0601 "A Mathematical Programming Method for Generating Alternative Managerial Performance Goals After Data Envelopment Analysis, " by Jeffrey D. Camm and Brian T. Downs

93-0602 "Empirical Methods in Corporate Finance used to Conduct Event Studies," by Rex Thompson

93-0801 "A Simple Method to Adjust Exponential Smoothing Forecasts for Trend and Seasonality," by Marion G. Sobol and Jim Collins

93-0901 "Leveraged Buyouts in the Late Eighties: How Bad Were They?" by Jean Helwege and Tim C. Opler

93-0902 "Stock Market Returns and Real Activity:

International Evidence," by Thomas C. Harris and Tim C. Opler

93-0914 "Quality Management at Kentucky Fried Chicken," by Uday M. Apte and Charles C. Reynolds

93-0915 "Global Disaggregation of Information-Intensive Services," by Uday M. Apte and Richard O. Mason

94-0101 "Financial Distress and Corporate Performance," by Tim C. Opler and Sheridan Titman

94-0102 "Models of Incentive Contracts for Just-in-Time Delivery," by John R. Grout

94-0103 "Economic Dependency on Work: A Moderator of the Relationship between Organizational Commitment and Performance," by Joan F. Brett, William L. Cron and John W. Slocum, Jr.

94-0201 "The Antecedents of Block Share Purchases," by Jennifer E. Bethel, Julia Porter Liebeskind, and Tim Opler

94-0202 "The New Learning Strategy: Anytime, Anything, Anywhere," by John W. Slocum, Jr., Michael McGill, and David T. Lei 
94-0401 "Leading Learning," by Michael E. McGill and John W. Slocum, Jr.

94-0402 "Systems Analysis," by Richard O. Mason and Sue A. Conger

94-0403 "The Moderating Effects of Insupplier/Outsupplier Status on Organizational Buyer Attitudes, " by Steven P. Brown

94-0404 "A Meta-analytic Study of Nomological Relationships Involving Work Performance and Job attitudes," by Steven P. Brown and Robert A. Peterson

94-0405 "Strategic Restructuring and Outsourcing: The Effect of Mergers and Acquisitions and LBOs on Building Firm Skills and Capabilities, " by David Lei and Michael A. Hitt

94-0406 "Corporate Diversification, Strategic Planning and Performance in Large Multiproduct Firms," by David Lei, Noel Capon, John U. Farley, and James M. Hulbert

94-0407 "Determination of Swap Spreads: An Empirical Analysis," by Andrew $\mathrm{H}$. Chen and Arthur $\mathrm{K}$. Selender

94-0408 "An Analysis of PERCS," by Andrew H. Chen, John Kensinger, and Hansong $\mathrm{Pu}$

94-0409 "Stock Price Reactions to the Passage of the Federal Deposit Insurance Corporation Improvement Act of 1991," by Andrew H. Chen, Marcia Millon Cornett, Sumon C. Mazumdar, and Hassan Tehranian 